\title{
Ekstrak Umbi Rumput Teki (Cyperus Rotundus) Sebagai Antibakteri Terhadap Staphylococcus Epidermidis Dan Propionibacterium Acnes
}

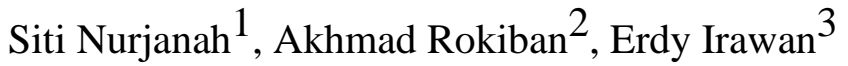 \\ 1,2,3 Jurusan Farmasi, Fakultas MIPA, Universitas Tulang Bawang Lampung \\ e-mail : titieajah05@gmail.com
}

Diterima : 03 November 2018. Disetujui: 20 November 2018. Dipublikasikan: 29 Desember 2018

\begin{abstract}
Abstrak
Umbi rumput teki merupakan salah satu jenis tumbuhan yang digunakan sebagai obat tradisional, yang diketahui mengandung senyawa metabolit sekunder seperti alkaloid, sineol, pinen, siperon, rotunol, siperenon, tanin, siperol, serta flavonoid dan secara ilmiah telah dipercaya memiliki aktivitas antimikroba. Secara empiris tanaman ini digunakan sebagai obat antibakteri, antitumor, antikanker, dan antialergi. Tujuan dari penelitian ini adalah untuk mengetahui daya hambat ekstrak umbi rumput teki sebagai antibakteri terhadap Staphylococcus epidermidis dan Propionibacterium acnes. Pada penelitian ini umbi rumput teki diekstraksi dengan cara maserasi menggunakan etanol $70 \%$. Ekstrak umbi rumput teki diuji terhadap bakteri $S$. epidermidis dan $P$. acnes menggunakan metode kertas cakram. Dari hasil penelitian didapatkan diameter rerata zona hambat pada konsentrasi 20\%, 40\%, 60\%, 80\%, dan 100\% pada bakteri S. epidermidis $8.03 \mathrm{~mm}, 11.43$ $\mathrm{mm}, 15.04 \mathrm{~mm}, 15.83 \mathrm{~mm}$ dan $19.98 \mathrm{~mm}$. Pada P. acnes $11.59 \mathrm{~mm}, 13.35 \mathrm{~mm}, 17.17$ mm, $20.44 \mathrm{~mm}$, dan $30.08 \mathrm{~mm}$. Aquades sebagai kontrol negatif dan eritromisin sebagai kontrol positif. Pengujian dilanjutkan dengan menentukan Konsentrasi Hambat Minimum (KHM). Hasil penelitian ini menunjukkan bahwa ekstrak umbi rumput teki dapat menghambat pertumbuhan bakteri pada semua konsentrasi. Makin besar konsentrasi ekstrak, maka semakin besar daya antibakteri yang ditimbulkan. Konsentrasi Hambat Minimum (KHM) yang dihasilkan pada bakteri S. epidermidis yaitu sebesar $15 \%$ bersifat bakteriostatik dan P. acnes sebesar $11 \%$ bersifat bakterisid.
\end{abstract}

Kata Kunci: Cyperus rotundus, Staphylococcus epidermidis dan Propionibacterium acnes, KHM

\section{Abstract}

The tuber of cyperus rotundus are used to tradisional medicine. C. rotundus known to contain compounds of secondary metabolites such as alkoloids, sineol, pinene, siperon, rotunal, siperenon, siperol, tannins, flavonoids and scientifically it has been believed to have antimicrobial activity. Empirically this plant are used as an antibacterial, antitumor, anticancer, and antiallergic. The purpose of this study were determining the inhibition of extract of Cyperus rotundus against tubers of Staphylococcus epidermidis and Propionibacterium acnes. In this study $C$. rotundus extracted by maceration using 70\% ethanol. The extracts tested against S. epidermidis and P. acnes using disc blank method. The results obtained from the mean diameter of the inhibition zones of exstract at concentrations of 20\%, 40\%, 60\%, 80\%, and 100\% on S. Epidermidis $8.03 \mathrm{~mm}, 11.43$ $\mathrm{mm}, 15.04 \mathrm{~mm}, 15.83 \mathrm{~mm}$ and $19.98 \mathrm{~mm}$ respectively and P. acnes $11.59 \mathrm{~mm}, 13.35 \mathrm{~mm}$, $17.17 \mathrm{~mm}, 20.44 \mathrm{~mm}$, and $30.08 \mathrm{~mm}$ respectively Aquades used as negative control and erythromycin used as positive control. Testing were continued by determining the 
Minimum Inhibitory Concentration (MIC). The result of MIC for S. epidermidis was $15 \%$ and $P$. acnes was $11 \%$. The analysis showed that the antibacterial activity of the tubers extract is bacteriostatic for $S$. epdermidis and bacterisid for $P$. acnes.

Keywords: Cyperus rotundus, Staphylococcus epidermidis, Propionibacterium acnes, MIC

\section{PENDAHULUAN}

Rumput teki ( $C$. rotundus) meskipun sebagai gulma, ternyata menyimpan berbagai manfaat pengobatan. Kegunaan rumput teki ( $C$. rotundus) adalah untuk menstabilkan siklus hormonal, obat sakit perut, obat untuk memperlancar kencing, obat cacingan, obat sakit gigi, untuk obat borok, radang kuku, nyeri lambung, kencing batu, luka terpukul, bisul, mual, muntah dan lain-lainnya. Umbi rumput teki (C. rotundus) mengandung alkaloid, sineol, pinen, siperon, rotunol, siperenon, tanin, siperol, serta flavonoid. Senyawa- senyawa tersebut pada umumnya berfungsi sebagai antibakteri, antitumor, antikanker, dan antialergi. Beberapa diantaranya dapat merusak membran sel bakteri dan mengerutkan dinding atau membran sel bakteri. Sehingga dapat menggangu permeabilitas sel bakteri, hingga pertumbuhan bakteri akan terhambat atau mati.

Staphylococcus epidermidis merupakan bakteri yang sering ditemukan sebagai floranormal pada kulit dan selaput lendir manusia. S. epidermidis merupakan salah satu bakteri gram positif berbentuk bulat, biasanya tersusun dalam rangkaian tidak beraturan seperti anggur dan bersifat anaerob fakultatif. Bakteri ini merupakan penyebab infeksi kulit ringan yang disertai abses. Bakteri ini juga berperan dalam pelepasan asam oleat, hasil hidrolisisnya oleh lipase yang diduga berpengaruh terhadap perkembangan jerawat Saraswati, F. N. (2015). Propionibacterium acnes adalah flora normal kulit terutama di wajah yang tergolong dalam kelompok bakteri Corynebacteria. Bakteri ini berperan pada patogenesis jerawat yang dapat menyebabkan inflamasi. Bakteri ini berbentuk batang dan dapat hidup di udara Inflamasi stratum serta menghasilkan spora. timbul karena perusakan corneum dan stratum germinativum dengan mensekresikan bahan kimia yang menghancurkan dinding pori, jerawat timbul karena asam lemak dan minyak kulit tersumbat Saraswati, F. N. (2015).

\section{METODE PENELITIAN}

Alat yang digunakan adalah cawan petri (Pyrex), pinset, jangka sorong (Mitutoyo), rotary evaporator (Scilogex RE100-Pro), pipet mikro (Socorex), jarum ose, 
autoklaf (Hirayama), tabung reaksi, rak tabung reaksi, beaker glass (Pyrex), inkubator (Memmert), erlenmeyer, gelas ukur, timbangan (Neraca Ohaus), lemari pendingin (Sharp), bunsen, corong pisah, kertas cakram, botol gelap, kain flannel. Bahan yang digunakan adalah umbi rumput teki ( $C$. rotundus), biakkan murni bakteri S. epidermidis dan P. acnes, media Nutrient Broth (NB), Nutrient Agar (NA), media Blood Agar Base, aquades, dan etanol $70 \%$.

\section{Pembuatan Ekstrak Simplisia}

Ekstraksi dilakukan dengan cara dingin yaitu maserasi yang bertujuan untuk menghindari agar senyawa tidak rusak. Umbi rumput teki yang sudah kering dimaserasi. Sebanyak 100 g dimasukkan kedalam erlenmeyer, kemudian direndam dengan larutan etanol $70 \%$, ditutup dengan aluminium foil dan dibiarkan selama 24 jam dan sesekali dilakukan pengadukan, peroses perendaman dilakukan sampai tersari sumpurna, lalu dievaporasi menggunakan rotaryevaporator, sehingga diperoleh ekstrak cairumbi rumput teki. Ekstrak yang dihasilkan dibiarkan pada suhu ruangan hingga seluruh pelarut etanol menguap. Ekstrak ditimbang dan disimpan dalam wadah gelap tertutup.

\section{Pembuatan Media}

Sebanyak 8 gram media Nutrient Agar (NA) dilarutkan dalam $400 \mathrm{~mL}$ aquades steril. Media dipanaskan sampai mendidih. Setelah itu dilakukan pengadukan dengan menggunakan magnetic stirrer untuk memastikan media tersuspensi sempurna. Setelah media tersuspensi sempurna, kemudian diautoklaf pada suhu $1210 \mathrm{C}$ selama 15 menit, lalu ditunggu sampai suhu hangat (400C - 450C). Nutrient Agar yang sudah siap, kemudian dituangkan sekitar $8 \mathrm{~mL}$ kedalam cawan petri steril dengan tingkat permukaan horisontal untuk memberikan kedalaman seragam $\pm 0,5 \mathrm{~cm}$. Media didiamkan sampai memadat (Ngajow, Abidjulu \& Kamu, 2013). Pembuatan media NB dengan cara melarutkan NB bubuk sebanyak 8 gram dalam 1 liter aquadest, dan dipanaskan hingga mendidih kurang lebih 10-15 menit. Setelah itu disterilkan dengan menggunakan autoklaf pada suhu $121{ }^{\circ} \mathrm{C}$ tekanan $1 \mathrm{~atm}$ selama 15 menit.

Pembuatan media BAB (Blood Agar Base) dilakukan dengan melarutkan 8 gram muler hilten dalam $200 \mathrm{ml}$ aquades hingga menjadi larutan yang homogen. Selanjutnya dipanaskan dalam penangas air selama 5 menit hingga mendidih. Darah manusia ditambah sebanyak $10 \mathrm{ml}$ aduk sampai homogen. Setelah dinginkan ad dengan aquades 
hingga $200 \mathrm{ml}$ kemudian campuran tersebut disterilkan menggunakan autoklaf pada temperatur $121^{\circ} \mathrm{C}$ dan tekanan 1 atm selama 15 menit (Ngajow, Abidjulu, \& Kamu, 2013).

\section{Penyiapan Biakan Bakteri}

Biakan murni bakteri S. Epidermidis diperbanyak dalam media NA dan P. Acnes diperbanyak dalam media $\mathrm{BAB}$ dengan menginokulasikan pada media agar miring, masing-masing diambil dari satu biakan dengan menggunakan jarum ose, kemudian digoreskan pada media agar miring dalam tabung dan diinkubasi selama 24 jam pada temperature $37^{\circ} \mathrm{C}$. Setelah biakan $S$. epidermidis dan $P$. acnes itu tumbuh, media agar miring tersebut disimpan pada lemari pendingin.

\section{Pembuatan Suspensi Bakteri}

Bakteri S. epidermidis dan P. acnes yang telah diperbanyak dalam cawan petri, diambil sebanyak satu mata ose kemudian disuspensikan kedalam media. Biakan bakteri tersebut kemudian dilakukan inkubasi selama 24 jam pada temperatur kekeruhannya. $37^{\mathrm{O}} \mathrm{C}$ dan dilihat kekeruhannya

\section{HASIL DAN PEMBAHASAN}

\section{Hasil Uji Daya Antibakteri}

Hasil uji daya antibakteri ekstrak umbi rumput teki terhadap bakteri Staphylococcus epidermidis dan Propionibacterium acnes menunjukkan adanya zona hambat disekitar kertas cakram pada konsentrasi 20\%, 40\%, 60\%, 80\%, 100\%, dan kontrol positif. Hasil uji daya antibakteri dapat dilihat pada Gambar 1 dan 4.2. Data rata-rata diameter zona hambat ekstrak umbi rumput teki terhadap S. epidermidis dan $P$. acnes dapat dilihat pada Tabel 1 dan Tabel 2. 


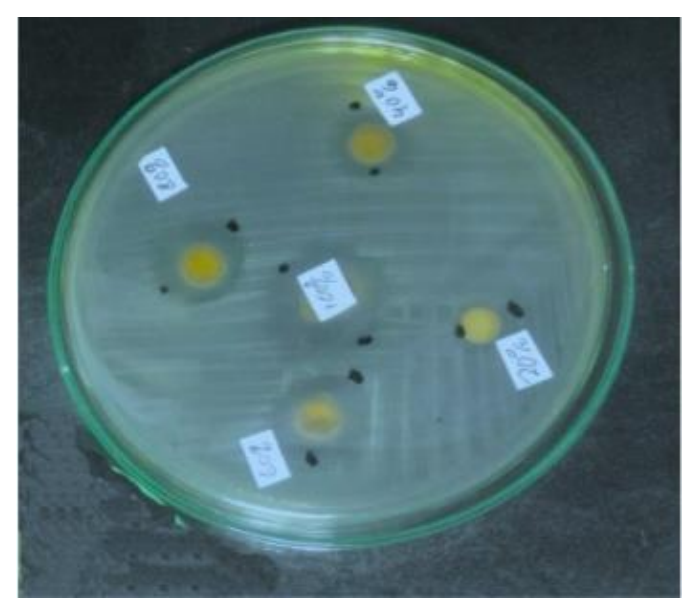

Gambar 1. Hasil uji daya antibakteri Ekstrak umbi rumput teki dengan konsentrasi $20 \%, 40 \%, 60 \%$, 80 dan 100\% terhadap bakteri S. epidermidis.

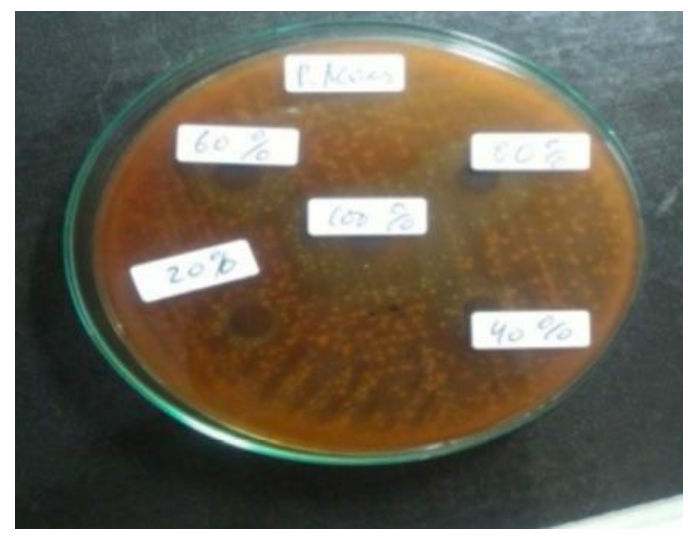

Gambar 2 Hasil uji daya antibakteri Ekstrak umbi rumput teki dengan konsentrasi 20\%, 40\%, 60\%, 80 dan 100\% terhadap bakteri P. acnes.

Tabel 1 Rata-rata diameter zona hambat ekstrak umbi rumput teki terhadap Bakteri S. epidermidis

\begin{tabular}{|c|c|c|c|c|c|}
\hline \multirow{2}{*}{ Perlakuan } & \multicolumn{3}{|c|}{ Ulangan (mm) } & \multirow{2}{*}{ Total } & \multirow{2}{*}{$\begin{array}{c}\text { Rata- } \\
\text { rata }\end{array}$} \\
\hline & 1 & 2 & 3 & & \\
\hline Kontrol - & 0 & 0 & 0 & 0 & $0^{\mathrm{a}}$ \\
\hline Kontrol + & 34.1 & 33.9 & 34.2 & 102.2 & $34.06^{\mathrm{g}}$ \\
\hline K 20\% & 8.04 & 8.05 & 8.01 & 24.1 & $8.03^{b}$ \\
\hline K $40 \%$ & 11.4 & 11.4 & 11.4 & 34.3 & $11.43^{\mathrm{c}}$ \\
\hline K 60\% & 15.01 & 15.11 & 15.02 & 45.14 & $15.04^{\mathrm{d}}$ \\
\hline K $80 \%$ & 15.7 & 15.8 & 16.01 & 47.51 & $15.83^{\mathrm{e}}$ \\
\hline K 100\% & 19.95 & 19.99 & 20.01 & 59.95 & $19.98^{f}$ \\
\hline
\end{tabular}

Angka - angka pada kolom yang sama diikuti huruf tika atas yang sama tidak berbeda nyata pada taraf uji $5 \%$

Keterangan : 
$\begin{array}{ll}\text { Kontrol }- & \text { : aquades } \\ \text { Kontrol }+ & : \text { eritromisin } \\ \text { K } & \text { : Konsenterasi ektrak umbi rumput teki }\end{array}$

Tabel 2 Rata-rata diameter zona hambat ekstrak umbi rumput teki terhadap Bakteri P. acnes

\begin{tabular}{|c|c|c|c|c|c|}
\hline \multirow{2}{*}{ Perlakuan } & \multicolumn{3}{|c|}{ Ulangan (mm) } & \multirow{2}{*}{ Total } & \multirow{2}{*}{$\begin{array}{c}\text { Rata- } \\
\text { rata }\end{array}$} \\
\hline & 1 & 2 & 3 & & \\
\hline Kontrol - & 0 & 0 & 0 & 0 & $0^{\mathrm{a}}$ \\
\hline Kontrol + & 38.9 & 38.7 & 38.54 & 116.14 & $38.71^{\mathrm{g}}$ \\
\hline K 20\% & 11.54 & 11.61 & 11.62 & 34.77 & $11.59^{\mathrm{b}}$ \\
\hline K 40\% & 13.31 & 13.29 & 13.45 & 40.05 & $13.35^{\mathrm{c}}$ \\
\hline K 60\% & 17.06 & 17.12 & 17.34 & 51.52 & $17.17^{\mathrm{d}}$ \\
\hline K $80 \%$ & 20.34 & 20.54 & 10.45 & 61.33 & $20.44^{\mathrm{e}}$ \\
\hline K $100 \%$ & 30.06 & 30.07 & 30.12 & 90.25 & $30.08^{f}$ \\
\hline
\end{tabular}

Angka - angka pada kolom yang sama diikuti huruf tika atas yang sama tidak berbeda nyata pada taraf uji $5 \%$

Keterangan :

Kontrol - $\quad$ : aquades

Kontrol $+\quad$ : eritromisin

K : Konsenterasi ektrak umbi rumput teki

Data diameter zona hambat yang diperoleh sebelum dianalisis terlebih dahulu dilakukan uji homogenitas. Hasil dari uji homogenitas diperoleh data yang homogen, kemudian dilanjutkan dengan uji ANOVA, dan diproleh nilai $p<0.05$ lalu dilanjutkan dengam uji lanjut LSD. Hasil analisis data dapat dilihat pada lampiran F.

Pada Tabel 1, diameter zona hambat S. epidermidis menunjukan bahwa pada konsentrasi $20 \%$ sudah menunjukan adanya zona hambat yang terbentuk yaitu sebesar $8.03 \mathrm{~mm}$, pada konsentrasi $40 \%$ zona hambat yang terbentuk adalah sebesar $11.43 \mathrm{~mm}$, konsentrasi $60 \%$ dan $80 \%$ masing - masing diperoleh zona hambat sebesar $15.04 \mathrm{~mm}$ dan $15.83 \mathrm{~mm}$. Zona hambat terbesar yang diperoleh dari konsentrasi sampel adalah konsentrasi $100 \%$ yaitu sebesar 19.98 mm, sedangkan kontrol positif diperoleh hasil sebesar 34,06 mm. Hasil uji ANOVA diperoleh nilai signifikan dengan $\mathrm{P}<0.05$. Sementara itu, hasil uji lanjut dengan menggunakan uji LSD menghasilkan nilai signifikan dengan $\mathrm{P}<0,05$ untuk tiap perlakuan. 
Pada Tabel 2 diameter zona hambat $P$. acnes menunjukan bahwa pada konsentrasi $20 \%$ sudah menunjukan adanya zona hambat yang terbentuk yaitu sebesar $11.59 \mathrm{~mm}$, pada konsentrasi $40 \%$ zona hambat yang terbentuk adalah sebesar 13.35 mm, konsentrasi $60 \%$ dan $80 \%$ masing - masing diperoleh zona hambat sebesar 17.17 $\mathrm{mm}$ dan $20.44 \mathrm{~mm}$. Zona hambat terbesar yang diperoleh dari konsentrasi sampel adalah konsentrasi $100 \%$ yaitu sebesar 30.08 mm, sedangkan kontrol positif diperoleh hasil sebesar $38.71 \mathrm{~mm}$.

Hasil uji ANOVA diperoleh nilai signifikan dengan $\mathrm{P}<0.05$. Sementara itu, hasil uji lanjut dengnan menggunakan uji LSD menghasilkan nilai signifikan dengan $\mathrm{P}<0,05$ untuk tiap perlakuan. Zona hambat yang terbentuk terhadap kedua bakteri berbanding lurus dengan besarnya konsentrasi sampel, semakin besar konsentrasi sampel semakin besar pula zona hambatnya. Bila dibandingkan dengan diameter zona hambat pada kontrol positif, maka diamater zona hambat kontrol positif lebih besar dari diameter ekstrak. Kontrol positif yang digunakan adalah eritromisin. Eritromisin merupakan antibiotik golongan makrolida dengan spektrum luas pada bakteri gram positif dan bakteri gram negatif. Kontrol negatif tidak menunjukan adanya zona hambat yang terbentuk.

Eritromisisn merupakan antibiotik golongan makrolida yaitu antibiotik yang memiliki cincin makrosiklik. Mekanisme kerja eritromisin sebagai antimikroba adalah dengan menghambat sintesis protein bakteri, dengan menyekat reaksi translokasi asil amino dalam riboson, degan pengikatan riboson bakteri yang kekuatannya bergantung pada struktur antibiotik dan RNA ribosom bakteri (Tjay, \& Rahardja, 2002).

Hasil penelitian uji daya hambat menunjukan bahwa ekstrak umbi rumput teki berpotensi sebagai antibakteri $S$. epidermidis dan $P$. acnes. Hal ini dikarenakan beberapa komponen dalam umbi rumput teki yaitu alkaloid, flavanoid, tanin, pati, glikosida dan furochromones, seskuiterpenoid dan saponin yang memiliki aktivitas antibakteri (Lawal, \& Oyedeji, 2009).

Senyawa flavonoid bekerja pada bakteri dengan cara merusak sel sitoplasma. Sel sitoplasma bakteri yang berfungsi mengatur masuknya bahan makanan dan nutrisi, apabila membrane sitoplasma rusak maka metabolit penting dalam bakteri akan keluar danbahan makanan untuk menghasilkan energi tidak dapat masuk sehingga sel bakteri tidak mampu tumbuh dan akhirnya terjadi kematian. Senyawa alkaloid memiliki 
mekanisme penghambatan dengan cara mengganggu komponen penyusun peptidoglikan pada sel bakteri sehingga lapisan dinding sel tidak terbentuk secara utuh dan menyebabkan kematian sel tersebut. Tanin merupakan senyawa organik yang memiliki senyawa komplek folifenol, tanin sebagai antibakteri tanin diduga berperan sebagai antibakteri karena memiliki kemampuan membentuk senyawa komplek dengan protein melalui ikatan hidrogen jika terbentuk ikatan hidrogen antara tanin dengan protein kemungkinan protein akan terdenaturasi sehingga metabolisme bakteri menjadi terganggu.

Komponen lain selain flavanoid yang terdapat pada umbi rumput teki yaitu senyawa saponin. Saponin yang terdapat pada umbi rumput tekitermasuk dalam kelompok antibakteri yang menggangu permeabilitas membran sel mikroba, yang mengakibatkan kerusakan membran sel dan menyebabkan keluarnya berbagai komponen penting dari dalam mikroba yaitu protein, asam nukleat, nukleotida dan lain - lain (Dharmananda, 2005). Penelitian lain mengenai minyak atsiri umbi rumput teki menunjukkan aktifitas antibakteri yang lebih baik terhadap bakteri gram positif khususnyaS. aureus dari penelitian tersebut dihasilkan bahwa cyperene $(30,09)$ maupun senyawa yang paling banyak bersifat antibakteri (Kilani, at al, 2005). Penelitian lain mengenai infusa umbi rumput teki terhadap E. Coli menghasilkan konsenterasi bunuh minimum (KBM) sebesar 40\% (8).

\section{Konsentrasi Hambat Minimum Dan Konsentrasi Bunuh Minimum}

Dilusi cair dilakukan untuk menentukan KHM, mulai dari konsentrasi $19 \%$ hingga $1 \%$. Hasil uji dilusi cair ekstrak umbi rumput teki terhadap S. epidermidis pada konsentrasi $1 \%$ - $14 \%$ memperlihatkan adanya pertumbuhan S. epidermidis, sedangkan pada konsentrasi 15\% - 19\% tidak terdapat pertumbuhan bakteri. Pada uji dilusi cair ekstrak umbi rumput teki terhadap $P$. acnes, konsentrasi $11 \%$ - 19\% tidak memperlihatkan adanya pertumbuhan bakteri, sedangkan pada konsentrasi $1 \%-10 \%$ memperlihatkan adanya pertumbuhan $P$. acnes (Gambar 3 dan Tabel 3) 


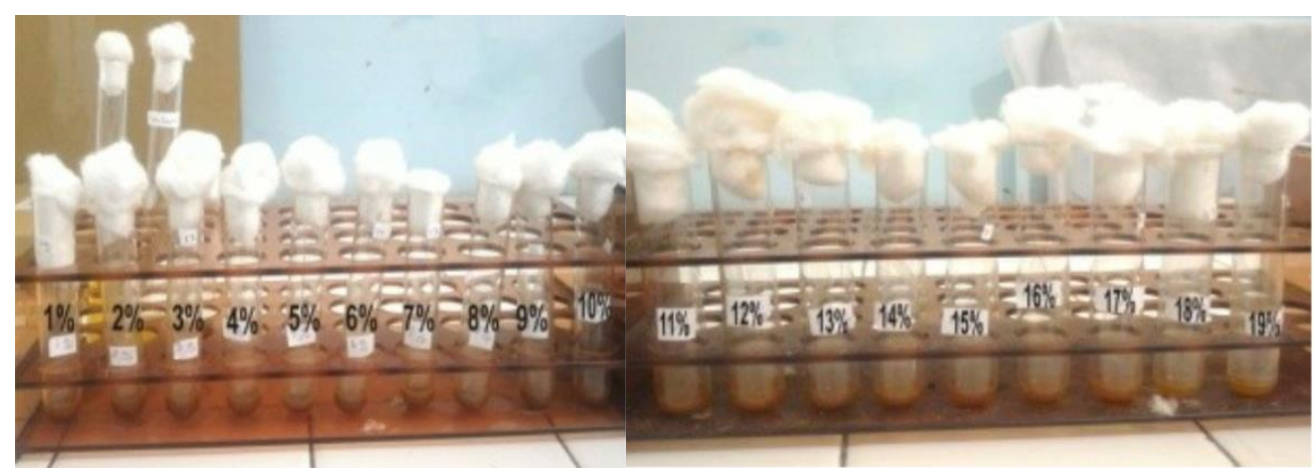

(A)

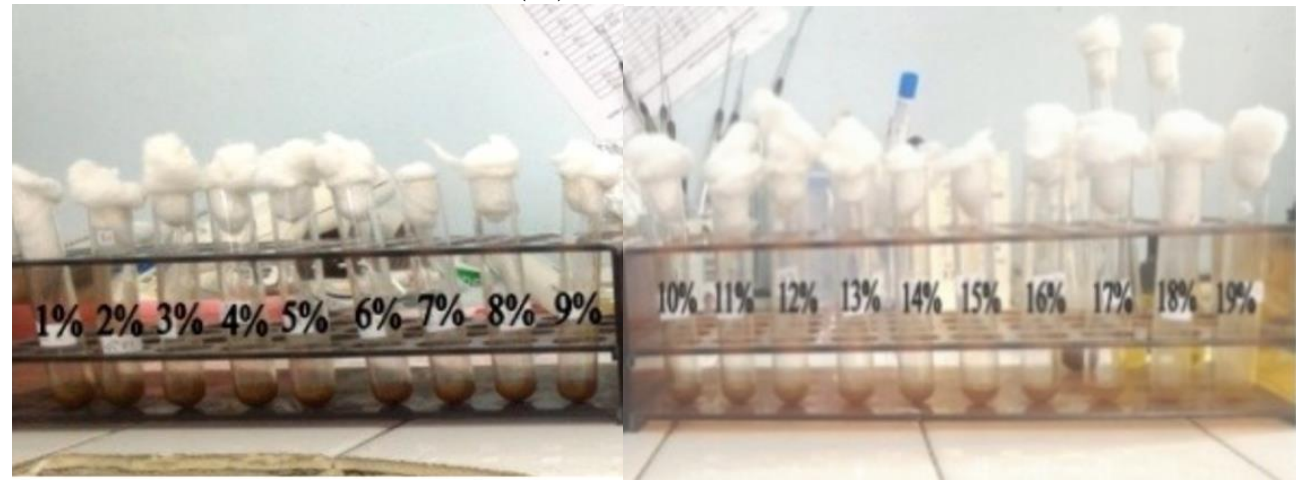

(B)

Gambar 3 Hasil uji konsentrasi hambat minimum ekstrak umbi rumput teki terhadap bakteri (A), (B) P. acnes dan (C), (D) S. epidermidis

Media yang tidak ada pertumbuhan bakteri kemudian dilakukan kultur ulang, pada konsentrasi ekstrak umbi rumput teki terhadap pertumbuhan S. epidermidis dari konsentrasi $15 \%$ - $16 \%$ dan konsentrasi ekstrak umbi rumput teki terhadap pertumbuhan $P$. acnes dari konsentrasi $11 \%$ - 12\% pada masing- masing ekstrak tidak ada pertumbuhan bakteri. Hasil kultur ulang dapat dilihat pada Gambar 4 dan Tabel 3.

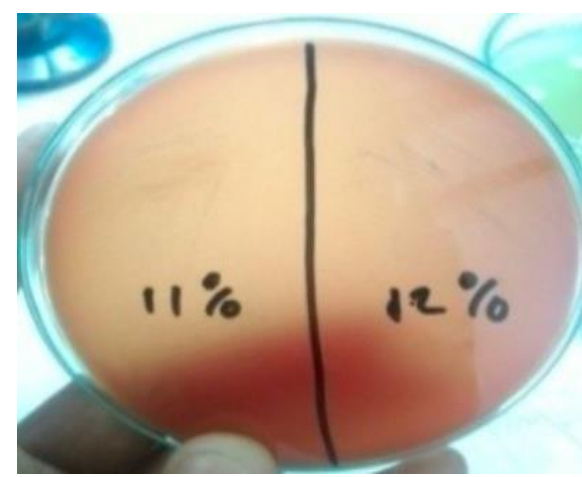

(A)

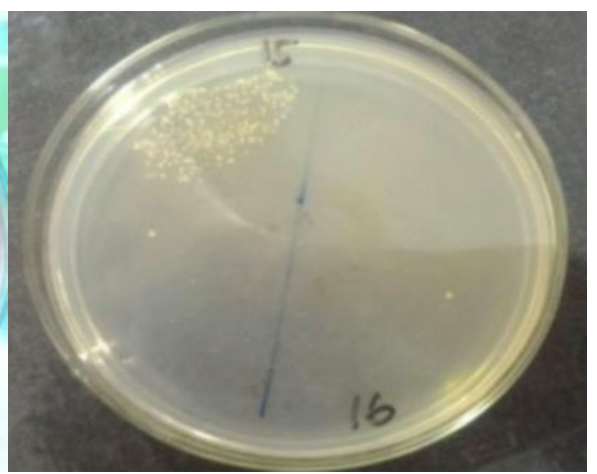

(B)

Gambar 4. Hasil uji konsentrasi bunuh minimum ekstrak umbi rumput teki bakteri (A) S .epidermidis dan (B) P. acnes.

Hasil uji KHM menunjukan bahwa konsentrasi $15 \%$ tidak terdapat pertumbuhan pada bakteri S. epidermidis dan pada konsentrasi $11 \%$ tidak terdapat pertumbuhan $P$. 
acnes. Kemudian konsentrasi yang tidak terdapat pertumbuhan bakteri digoreskan kemedia agar untuk menentukan KBM (konsentrasi bunuh minimum) dan melihat ada pertumbuhan bakteri atau tidak ada pertumbuhan bakteri. Dari hasil uji KBM maka dapat diketahui bahwa ekstrak umbi rumput teki bersifat bakteriostatik pada bakteri $S$. epidermidis, hal ini dapat terlihat adanya pertumbuhan bakteri pada konsentrasi $15 \%$ 19\%, namun pada bakteri $P$. acnes ekstrak umbi rumput teki bersifat bakterisid, hal ini dapat terlihat tidak adanya pertumbuhan bakteri pada konsentrasi 11\% - 19\%.

Dari penelitian lainya umbi rumput teki menghasilkan KHM terhadap Sthaphylococcus aureus sebesar 12,5\% (7). Berdasarkan dari bebrapa pembahasan yang telah dilakukan, maka ekstrak umbi rumput teki dapat digunakan sebagai alternatif pengobatan jerawat yang disebabkan oleh bakteri S. epidermidis dan P. Acnes (Septiani, F. (2015).

Tabel 3 Hasil uji konsentrasi hambat ekstrak umbi rumput teki terhadap pertumbuhan bakteri S. epidermidis dan P. acnes

\begin{tabular}{lccc}
\hline No & Konsenterasi & $\begin{array}{c}\text { Pertumbuhan } \\
\text { S.epidermidis }\end{array}$ & $\begin{array}{c}\text { Pertumbuhan } \\
\text { P.acnes }\end{array}$ \\
\hline 1 & $20 \%$ & - & - \\
2 & $19 \%$ & - & - \\
3 & $18 \%$ & - & - \\
4 & $17 \%$ & - & - \\
5 & $16 \%$ & - & - \\
6 & $15 \%$ & + & - \\
7 & $14 \%$ & + & - \\
8 & $13 \%$ & + & - \\
9 & $12 \%$ & + & - \\
10 & $11 \%$ & + & - \\
11 & $10 \%$ & + & + \\
12 & $9 \%$ & + & + \\
13 & $8 \%$ & + & + \\
14 & $7 \%$ & + & + \\
15 & $6 \%$ & + & + \\
16 & $5 \%$ & + & + \\
17 & $4 \%$ & + & + \\
18 & $3 \%$ & + & + \\
19 & $2 \%$ & + & + \\
20 & $1 \%$ & - & - \\
21 & Kontrol Media & - & + \\
22 & Kontrol Larutan & + & + \\
& Uji & + & + \\
23 & Kontrol Media & & + \\
\hline
\end{tabular}


Keterangan : Tanda (-) menunjukkan tidak adanya pertumbuhan bakteri Tanda (+) menunjukkan adanya pertumbuhan bakteri

\section{KESIMPULAN}

Kesimpulan dari penelitian ini yaitu bahwa ekstrak umbi rumput teki mempunyai daya antibakteri terhadap pertumbuhan $S$. epidermidis dengan KHM sebesar $15 \%$ bersifat bakteriostatik, sedangkan P. acnes dengan KBM sebesar $11 \%$ bersifat bakterisid.

\section{SARAN}

Berdasarkan penelitian yang dilakukan maka penelitian lebih lanjut disarankan untuk dapat membuat sediaan farmasi.

\section{DAFTAR PUSTAKA}

2- Saraswati, F. N. (2015). Uji Aktivitas Antimikroba Ekstrak Etanol 96\% Limbah Kulit Pisang Kepok Kuning (Musa balbisiana) Terhadap Bakteri Penyebab Jerawat (Staphylococcus epidermidis, Staphylococcus aureus, dan Propionibacterium acne) (Bachelor's thesis, UIN Syarif Hidayatullah Jakarta: Fakultas Kedokteran Dan Ilmu Kesehatan, 2015).

3-Ngajow, M., Abidjulu, J., \& Kamu, V. S. (2013). Pengaruh antibakteri ekstrak kulit batang matoa (Pometia pinnata) terhadap bakteri Staphylococcus aureus secara in vitro. Jurnal MIPA, 2(2), 128-132.

4- Tjay, T. H., \& Rahardja, K. (2002). Obat-obat penting khasiat, penggunaan, dan efek-efek sampingnya (Edisi VI). Jakarta: PT. Elex Media Komputindo, 31(3), $0-355$.

5- Lawal, O., \& Oyedeji, A. (2009). Chemical composition of the essential oils of Cyperus rotundus L. from South Africa. Molecules, 14(8), 2909-2917.

6- Dharmananda, S. (2005). Cyperus: Primary Qi Regulating Herb of Chinese Medicine. ITM.

7- Kilani, S., Abdelwahed, A., Ammar, R. B., Hayder, N., Ghedira, K., Chraief, I., ... \& Chekir-Ghedira, L. (2005). Chemical composition, antibacterial and antimutagenic activities of essential oil from (Tunisian) Cyperus rotundus. Journal of Essential Oil Research, 17(6), 695-700.

8- Septiani, F. (2015). Daya antibakteri infusa umbi rumput teki (cyperus rotundus l.) Terhadap Escherichia coli secara in vitro (Doctoral dissertation, Universitas Airlangga). 